\title{
Gateway for alternative protein production
}

Keywords: Global human population growth, world population, protein bank, entomophagy

\section{Introduction}

Global human population growth is estimated to be around 75 million annually, which is $1.1 \%$ per year. The world population has grown from 1 billion in 1800 to 7 billion in 2012. It has also been estimated that the world population will be around 8-10 billion in 2050. Based on several observations, the human population growth on Earth can be divided into 3 distinct phases. The first phase (premodern phase) was characterized by very slow population growth. The second phase, beginning with the onset of modernity (lasted till 1962) exhibited an increasing rate of population growth. Currently we are passing through the third phase of population growth where the growth rate is gradually stabilizing and experiencing a decreasing phase.

India's population is about $17.86 \%$ of the total world population and ranks number two in the list of countries by population. The current population of India on July13, 2017 is 1,342,934,169. ${ }^{1}$ The population forecast in India in 2050 is around 1,705,332,544. ${ }^{1}$ This enormous population requires a huge protein bank due to limitation in land and water resources. The supply of protein from these sources has almost touched the critical level. The protein production is experiencing a slow pace and the supply chain is gradually subsiding. It is in this context that there is an utmost need of alternative protein sources, which can, for instance be obtained from insects. Edible insects have always been a part of human diet, and in many countries

\author{
Volume I Issue 2 - 2017
}

\section{Chowdhury GR,' Mukherjee P, Biswas P, Chowdhury RR, ${ }^{2}$ Zaman S, ${ }^{3}$ Mitra $A^{4}$ \\ 'Techno India University, India \\ ${ }^{2}$ Department of Biotechnology, Techno India University, India ${ }^{3}$ Department of Oceanography, Techno India University, India ${ }^{4}$ Department of Marine Science, University of Calcutta, India}

Correspondence: Abhijit Mitra, Department of Marine Science, University of Calcutta, 35 BC Road, Kolkata 700019, India,Email abhijit_mitra@hotmail.com

Received: July 15, 2017 | Published: August 16, 2017

they are consumed either as whole or as ingredient to other food. More than 1900 insect species are reportedly used as food. Globally, the most commonly consumed insect are beetles (Coleoptera; 31\%) followed by caterpillar (under Lepidoptera; 81\%), bees, wasps, ants, under (Hymenoptera; 14\%). In addition grasshoppers, locusts, crickets (Orthoptera), true bugs and scaled insects (Heminoptera) are also consumed.

In this paper, we present a first order analysis of the scope of insects to be used as food. In this table we present three major benefits associated with entomophagy (Table 1).

Table I Benefits of using insect as protein source

\begin{tabular}{ll}
\hline Sector & Benefits \\
\hline Health & $\begin{array}{l}\text { Insects are rich in protein compared to mutton, beef and chicken. The protein percentages in the adult } \\
\text { and larvae of the orders Coleoptera, Lepidoptera, Hemiptera, Homoptera, Hymenoptera, Odonata, } \\
\text { Orthoptera range between } 23-66 \%, 14-68 \%, 42-74 \%, 45-57 \%, 13-77 \%, 46-65 \%, 23-65 \% \text { respectively. }\end{array}$ \\
\hline Environment & I. Insects play an important role in reducing the emission and Green House Gas compared to livestock. \\
\hline & $\begin{array}{l}\text { 2. Insects feed on organic waste which otherwise would have emitted Green House Gas to the } \\
\text { atmosphere. }\end{array}$ \\
\hline $\begin{array}{l}\text { 3. The ammonia emission associated with insect rearing is far lower than that linked to conventional } \\
\text { livestock such as pigs. }\end{array}$ & $\begin{array}{l}\text { I. Rearing and breeding insects for human consumption or for production of fish food in aquaculture etc. } \\
\text { can be a gateway to alternative livelihood opportunities for rural populations }\end{array}$ \\
\hline $\begin{array}{l}\text { 2. Processing and preparing insect to produce powder, paste or other food ingredients can be source of } \\
\text { income for people related with Food Technology, Microbiology, Biotechnology and other branches of Life } \\
\text { Science. }\end{array}$
\end{tabular}

Source Xiaoming et al.3

\section{Insects: a protein bank}

Insects are basically the protein bank of planet Earth. Considering the protein level of edible insects, it is high time to initiate entomofarming (Figure 1). This can be a road map for alternative livelihood, employment opportunities, and food security. However, the protein content of insects is a function of the stages of their life cycle. It has been found that the protein content is maximum in adult insect, as witnessed in case of variegated grasshoppers Zonocerus variegates (raw) (Figure 2). Ademolu et al. ${ }^{2}$ and Xiaoming et al. ${ }^{3}$ evaluated the protein content of 100 species from five orders of Insecta, and observed a protein range between $13-77 \%$ of dry matter (Figure 2). 
The present article thus points towards a non-conventional gateway of protein production for the rapidly increasing human population on Earth. This particular vertical can also be a source of alternative livelihood for rural populations and thus may be a road map to reduce poverty and unemployment in the developing nations of the world.

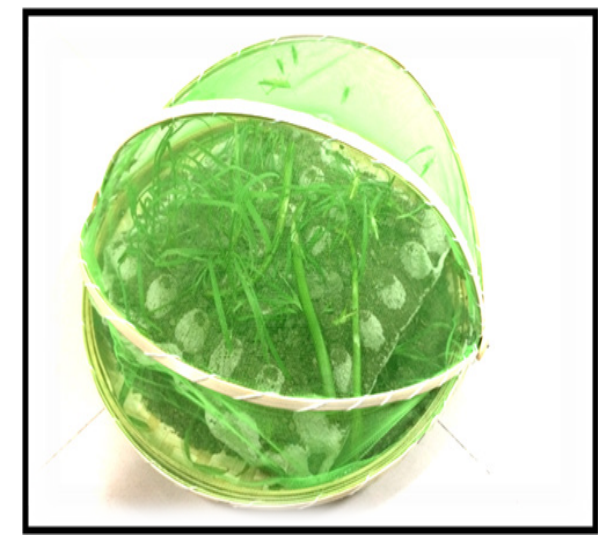

Figure I Grasshopper (Zonocerus variegates) rearing model unit at Techno India University, West Bengal.

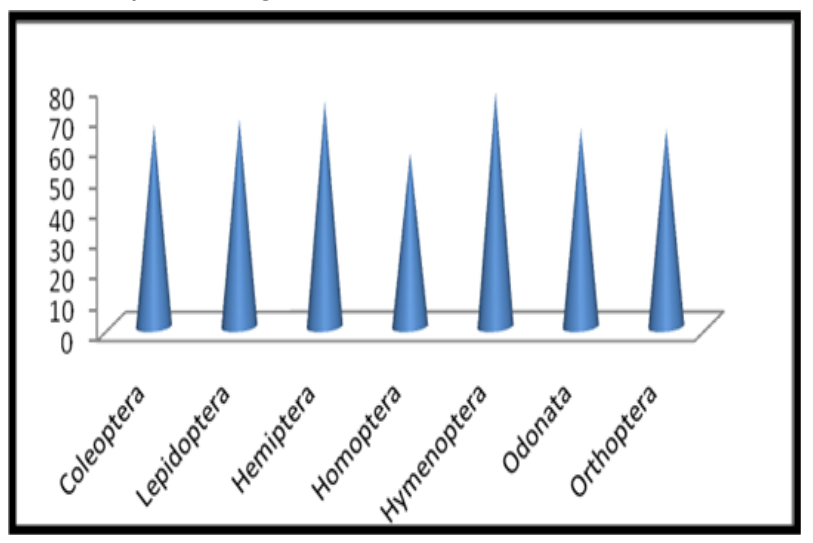

Figure 2 Percentages of crude protein content in different orders of class Insecta. The orders are placed in the $\mathrm{X}$-axis and the protein percentages are presented in the Y-axis.

\section{Acknowledgments}

None.

\section{Conflict of interest}

Authors declare there is no conflict of interest.

\section{References}

1. www.worldmeters.info/world-poulation/india-population/

2. Ademolu KO, Idowu AB, Olatunde GO. Nutritional value assessment of variegated grasshopper, Zonocerus variegatus (L.) (Acridoidea: Pygomorphidae), during post-embryonic development. African Entomology. 2010;18(2):360-364.

3. Xiaoming $\mathrm{C}$, Ying $\mathrm{F}$, Hong $\mathrm{Z}$, et al. Review of the nutritive value of edible insects. In: Durst PB, DV Johnson, editors. Forest insects as food: humans bite back, proceedings of a workshop on Asia-Pacific resources and their potential for development. FAO Regional Office for Asia and the Pacific, Bangkok, Thailand; 2010. p. 19-21. 